\title{
PAPA BEAR
}

Cold comfort.

\section{BY KURT PANKAU}

$\mathrm{I}$ mages flash in my head. Evacuations. Fires. Bodies. The long winter.

Cold. I'm on a mattress on the floor, one arm draped over a woman I don't recognize. It's dark, but I can see wheel wells. So it's not the floor - the back of a truck, maybe? A van?

The sleeping woman in front of me is facing away, but her face looks young, maybe early forties. She's wrapped in several layers of ragged clothing. And so am I, I realize. I reach a hand up to feel my face and find a thick beard. I never wore a beard. I don't have the slightest idea how to maintain one.

I sit up and place a hand on the window. There's a curtain, but through the thin cloth I can feel the freezing pane of glass. I pull aside the curtain and I can see a foot of snow reflected in the moonlight. The sky is dark purple. I grope around for the door.

Where am I?

"Albuquerque, I think," says the woman. "Come back to bed, Papa Bear." I don't recognize her voice.

"I'm just going to take a leak," I say. I need to get out of here.

"We emptied your bag three hours ago," she said.

I reach a hand instinctively to my middle and feel a twitch in my abdomen as my fingers nudge a plastic line attached to the stoma near my ... How do I know what a stoma is?

"Come back to bed."

"Who are you?" I ask.

"It's me," she says. "Lisa."

"Lisa's long dead," I say. How do I know that? Dear God, Lisa. When did she die?

"Dammit," says the woman.

"Why did you say that?" I ask, my anger rising. "Why would you pretend to be my wife?"

"I wasn't pretending to be your wife." The woman makes a snorting noise. "I never know what you're going to remember."

"Remember?"

"During your spells."

“Spells?" I fumble for the door.

ONATURE.COM Follow Futures:

\section{y @NatureFutures}

f go.nature.com/mtoodm
"Please don't," she says. "If you let in the cold air, we may freeze."

"Then turn on the

engine," I say, moving to the front of the van. There's no key, but the panel under the steering wheel has been ripped off and wires dangle, exposed. The passenger's seat is filled with gasoline cans and jugs of water.

Scraps of paper with a tangle of notes in my handwriting. My fingers are trembling. Letters to myself. Pieces of a puzzle I can't quite assemble.

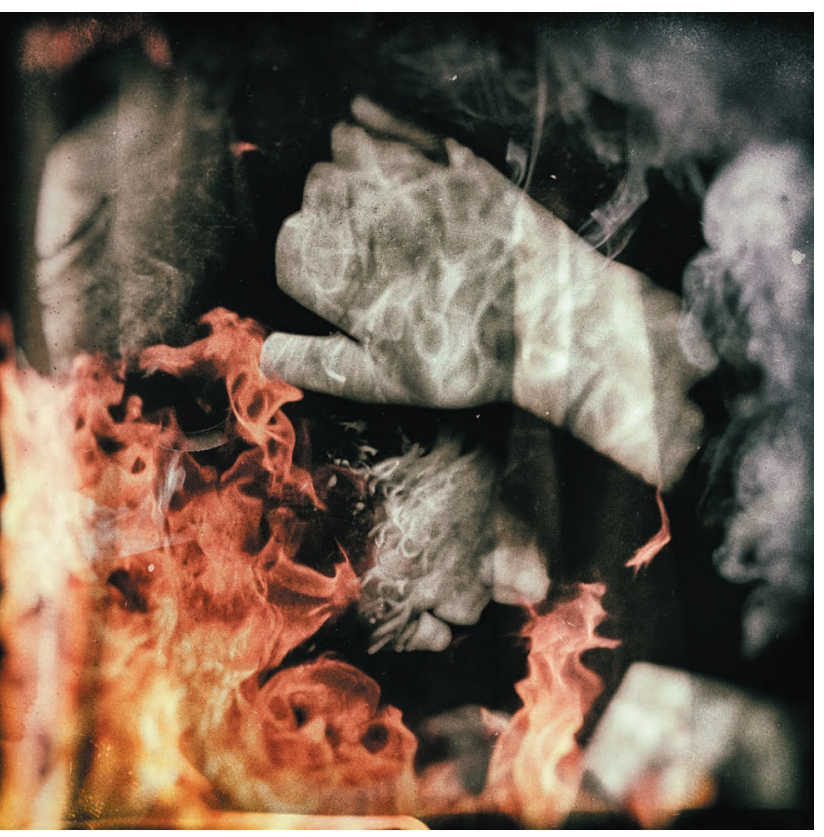

It's like the past...

"Like the past is running away from you?"

I feel hands on my shoulder and her nose on the back of my neck. The touch is familiar.

"How did you know —?" I start to ask.

"You were thinking out loud," says the woman. "You do that."

"Oh," I say.

"I'm cold, Papa Bear," she says. "Please come back to bed. I'll explain in the morning."

"Explain it to me now," I say, turning to face her. "Tell me everything."

"You'll never get back to sleep," says the woman. "There's too much. Come back to bed. I want you to sing to me."

"Who are you?" I ask.

"I’m your wife," she says.

"Lisa’s dead," I say.

"So is my first husband. So are a lot of people." She wraps her arms around my neck and presses her lips to mine. The hairs of my beard rub against my chin and tickle my face. The kiss is brief, but I know those lips. She pulls back and rests her forehead against mine.

"Tell me your name, at least," I say.

"Jennifer," she says. Her voice is quavering.

Oh no, I've done something wrong.

"No, you haven't," she says, shaking her head gently.

"I'm just ... I'm having trouble," I say. My voice is hoarse and raspy.

"I know, Papa Bear," she says, sniffling. "I promise, I'll tell you everything in the morning. Just come back to bed."

"Why are you crying?" I ask.

"Because a long time ago, the world ended," she says. "The world ended and you saved us and I fell in love with you. And because nobody else gives a damn about you, even though you saved all our lives" - she swallows hard - "because you get confused sometimes."

I look out the window. There are a dozen other cars around us. Like a caravan. Beyond them, lean-tos and the skeletons of small structures. They're building something. No, they're rebuilding. Why? We need to stay mobile. Don't we?

"I know where this conversation is heading and I can't do it again, not tonight," she says. "I just can't. Please come to bed. I promise, everything will be better in the morning. Just come back to bed." Tears glisten in the moonlight. In this cold, they must sting her cheeks.

I nod. She pulls me back to the mattress. She lies down and holds my arm tightly to her chest. Her face flashes through my mind. I can feel the weight of a thousand memories hidden behind a fog.

"I love you, Papa Bear," she says. Her voice is almost a whimper.

"I love you too, Baby Bear," I say, more from instinct than memory.

Her gentle sob is interrupted by a burst of tearful laughter. I guess I've remembered something important. I pull her closer to me, to shut out the cold, the emptiness, the void in my head where the past should be. I close my eyes.

Everything will be better in the morning.

Kurt Pankau lives with his family in St Louis, Missouri. He loves board games, dad jokes and stories about time travel. He tweetsat @kurtpankau and occasionally blogs at kurtpankau.com. 